\title{
Reduction in Enteroccocus faecalis counts produced by three file systems in severely curved canals
}

\author{
Redução nas contagens de Enteroccocus faecalis produzida por três sistemas de limas em \\ canais severamente curvos
}

Reducción de los recuentos de Enteroccocus faecalis producidos por tres sistemas de archivos en canales muy curvados

Wayne Martins Nascimento ORCID: https://orcid.org/0000-0003-4201-4710 São Leopoldo Mandic, Brazil

E-mail: waynemartins@gmail.com

Ana Grasiela da Silva Limoeiro

ORCID: https://orcid.org/0000-0003-4633-720X Faculdade de Ilhéus, Brazil

E-mail: grasielalimoeiro@gmail.com

Mariana Montagner Moraes

ORCID: https://orcid.org/0000-0003-0026-7672 São Leopoldo Mandic, Brazil

E-mail: mari.mmoraes@hotmail.com

Danilo De Luca Campos

ORCID https://orcid.org/0000-0003-0242-2429 São Leopoldo Mandic, Brazil

E-mail: danilo_campos17@hotmail.com

João Paulo Drumond

ORCID: https://orcid.org/0000-0001-6149-7389 São Leopoldo Mandic, Brazil

E-mail: drumond.endodontia@outlook.com

Walber Maeda

ORCID: https://orcid.org/0000-0002-0832-0776 São Leopoldo Mandic, Brazil

E-mail: walbermaeda@gmail.com

Adriana de Jesus Soares ORCID: https://orcid.org/0000-0002-8078-1606

Universidade Estadual de Campinas, Brazil

E-mail: ajsoares.endo@uol.com.br

Marina Carvalho Prado

ORCID: https://orcid.org/0000-0002-7116-0402

Universidade Estadual de Campinas, Brazil

E-mail: marinaprado@dentistas.com.br

Marcos Frozoni

ORCID: https://orcid.org/0000-0001-8001-4063

São Leopoldo Mandic, Brazil

E-mail: marcosfrozoni@gmail.com.br

\begin{abstract}
Aim: This study evaluated the effectiveness of the mechanical reduction of intracanal bacteria produced by the endodontic systems Reciproc Blue (VDW GmbH), XP-Endo Shaper (FKG Dentaire) and ProTaper Next (Dentsply Sirona Endodontics) in severely curved canals by culture analysis. Methodology: Fifty severely curved mesiobuccal canals of mandibular molars were selected and instrumented. Following this, six specimens were selected as control, while 44 canals were contaminated with Enterococcus faecalis strains (ATCC 29212). Specimens were incubated for 21 days at $37^{\circ} \mathrm{C}$. Then, contaminated specimens were randomly divided into 3 groups $(n=14)$ : ProTaper Next (G1), XPEndo Shaper (G2) and Reciproc Blue (G3). Control Group: Six non-contaminated canals were prepared with one of the 3 file systems $(n=2)$. Microbial samples were obtained before (S1) and after root canal preparation (S2). Two roots were observed using scanning electron microscopy to verify biofilm formation. Quantitative culture analyses of intracanal E. faecalis reduction was performed using CFUs, and the Wilcoxon test was used for intragroup analysis, and intergroup analysis was performed using Kruskal-Wallis test. The level of significance for all analyses was set at P $<.05$. Results:
\end{abstract}


All systems presented effective bacterial reduction $(\mathrm{p}<0.05)$, but still had bacterial growth. ProTaper Next displayed the highest E. faecalis reduction $(\mathrm{P}<0.05)$, while XP-Endo Shaper and Reciproc Blue systems presented similar results $(\mathrm{P}>0.05)$. ProTaper Next showed the greatest antibacterial action when compared to the XP-Endo Shaper and Reciproc Blue systems. Conclusion: No instrumentation system rendered root canals completely free from bacteria.

Keywords: Endodontics; Microbiology; Root canal therapy.

\section{Resumo}

Objetivo: Este estudo avaliou a eficácia da redução mecânica de bactérias intracanal produzidas pelos sistemas de limas Reciproc Blue (VDW GmbH), XP-Endo Shaper (FKG Dentaire) e ProTaper Next (Dentsply Sirona Endodontics) em canais severamente curvos por análise de cultura. Metodologia: Cinquenta canais mesio-vestibulares severamente curvos de molares inferiores foram selecionados e instrumentados. Em seguida, seis espécimes foram selecionados como controle, enquanto 44 canais foram contaminados com cepas de Enterococcus faecalis (ATCC 29212). Os espécimes foram incubados por 21 dias a $37^{\circ} \mathrm{C}$. Em seguida, os espécimes contaminados foram divididos aleatoriamente em 3 grupos $(n=14)$ : ProTaper Next $(\mathrm{G} 1)$, XP-Endo Shaper $(\mathrm{G} 2)$ e Reciproc Blue (G3). Grupo Controle: Seis canais não contaminados foram preparados com um dos 3 sistemas de limas $(n=2)$. Amostras microbianas foram obtidas antes (S1) e após o preparo do canal radicular (S2). Duas raízes foram observadas usando microscopia eletrônica de varredura para verificar a formação de biofilme. A análise quantitativa de cultura da redução intracanal de E. faecalis foi realizada usando UFC (unidade formadora de colônia), e o teste de Wilcoxon foi usado para a análise intragrupo, e a análise entre os grupos foi realizada usando o teste de Kruskal-Wallis. O nível de significância para todas as análises foi estabelecido em P <0,05. Resultados: Todos os sistemas apresentaram redução bacteriana efetiva ( $\mathrm{p}<0,05)$, mas ainda houve crescimento bacteriano. ProTaper Next apresentou a maior redução de E. faecalis $(\mathrm{P}<0,05)$, enquanto os sistemas XPEndo Shaper e Reciproc Blue apresentaram resultados semelhantes (P>0,05). ProTaper Next demonstrou a maior ação antibacteriana quando comparado com os sistemas XP-Endo Shaper e Reciproc Blue. Conclusão: Nenhum sistema de instrumentação tornou os canais radiculares completamente livres de bactérias.

Palavras-chave: Endodontia; Microbiologia; Tratamento do canal radicular.

\section{Resumen}

Objetivo: Este estudio evaluó la eficacia de la reducción mecánica de las bacterias intracanal producidas por los sistemas de endodoncia Reciproc Blue (VDW GmbH), XP-Endo Shaper (FKG Dentaire) y ProTaper Next (Dentsply Sirona Endodontics) en canales muy curvados mediante análisis de cultivo. Metodología: Se seleccionaron y prepararon 50 conductos mesiobucales severamente curvados de molares mandibulares. A continuación, se seleccionaron seis muestras como control, mientras que 44 canales se contaminaron con cepas de Enterococcus faecalis (ATCC 29212). Las muestras se incubaron durante 21 días a $37^{\circ} \mathrm{C}$. Luego, las muestras contaminadas se dividieron aleatoriamente en 3 grupos $(\mathrm{n}=14)$ : ProTaper Next $(\mathrm{G} 1)$, XP-Endo Shaper $(\mathrm{G} 2)$ y Reciproc Blue $(\mathrm{G} 3)$. Se prepararon seis canales no contaminados con uno de los 3 sistemas de archivos $(\mathrm{n}=2)$. Se obtuvieron muestras microbianas antes $(\mathrm{S} 1)$ y después de la preparación del conducto radicular (S2). Se observaron dos raíces usando microscopía electrónica de barrido para verificar la formación de biopelículas. Se realizaron análisis cuantitativos de cultivo de reducción intracanal de E. faecalis utilizando UFC, y se utilizó la prueba de Wilcoxon para el análisis intragrupo, y el análisis intergrupal se realizó mediante la prueba de Kruskal-Wallis. El nivel de significancia para todos los análisis se estableció en $\mathrm{P}<0,05$. Resultados: Todos los sistemas presentaron una reducción bacteriana efectiva ( $\mathrm{p}<0.05)$, pero aún tenían crecimiento bacteriano. ProTaper Next mostró la mayor reducción de E. faecalis $(\mathrm{P}<0.05)$, mientras que los sistemas XP-Endo Shaper y Reciproc Blue presentaron resultados similares ( $>>0.05$ ). ProTaper Next mostró la mayor acción antibacteriana en comparación con los sistemas XP-Endo Shaper y Reciproc Blue. Conclusión: Ningún sistema de instrumentación dejó los conductos radiculares completamente libres de bacterias.

Palabras clave: Endodoncia; Microbiologia; Tratamiento del conducto radicular.

\section{Introduction}

The main goals of root canal therapy are eliminating microorganisms, pulp tissue, and debris from the root canal system and enlarging the root canal diameter to supply enough space for the filling material (Schilder, 1974). However, it is known that most of the available systems fail to perform adequate cleaning and shaping, leaving untouched areas within the root canal (De Deus, et al., 2010; Versiani, et al. 2011) due to the challenges involved during endodontic treatment (isthmuses, intercanal communications, and oval-shaped canals) (Plotino et al. 2016). The curved canals may also limit the ideal mechanical preparation of the root canals and in turn may lead to the development of some procedural errors resulting in endodontic failure (Mounce, 2007). 
Recent advances in the field of endodontics have led to the use of nickel-titanium (NiTi) rotary instruments in endodontic practice (Patnana \& Chugh, 2018). The NiTi rotary files have become popular instruments to shape root canals because of their elasticity, efficiency, and cutting capacity (Ankrum et al., 2004). ProTaper Next (Dentsply Sirona Endodontics, York, PA, USA) is a multi-file system made from NiTi M-wire, largely used in endodontic treatment since extensive evidence supports these instruments (Machado et al., 2013; Machado et al., 2017; Krokidis et al., 2017). It has an off-centred rectangular cross-section that, according to the manufacturer, causes the files to advance in a snake-like manner into the root canal (Burklein et al., 2015).

Nevertheless, considerable interest in single-file systems has emerged resulting from treatment optimization and a growing body of studies that also indicate their use (Üreyen 2019; Aksoy et al., 2019; De Deus et al., 2019). XP-endo Shaper (XP) (FKG Dentaire, La Chaux-de-Fonds, Switzerland), a snake-shaped NiTi rotary system was recently introduced. According to the manufacturer instructions (FKG, 2017), the file has a taper of 0.01 in its M-phase when it is cooled and the taper changes to 0.04 at body temperature $\left(35^{\circ} \mathrm{C}\right)$ by the molecular memory in A-phase. The metallurgic alloy provides high flexibility to the file, and XP is expected to produce minimal stress on the dentin walls (Üreyen 2019; Aksoy et al., 2019; FKG, 2017). Another single file NiTi instrumentation system was introduced: Reciproc Blue (RB) (VDW GmbH, Munich, Germany), with an innovative heating process, used to modify its molecular structure for improving flexibility and resistance to cyclic fatigue (Aksoy et al., 2019; De Deus et al., 2019). High efficiency and cutting performance are provided with the combination of Sshaped cross-section, taper, cutting angles, and thermally improved material. The instrument has a noncutting tip, resistance to cyclic fatigue, and high flexibility, enabling better centering between canal walls (Aksoy et al., 2019; De Deus et al., 2019).

However, evaluating the capacity of these newly developed files in the mechanical bacterial reduction in severely curved canals is still scarce in the literature. Therefore, the purpose of this study was to evaluate the mechanical reduction of intracanal bacteria produced by ProTaper Next, XP-Endo Shaper, and Reciproc Blue systems in severely curved canals by culture analysis.

\section{Methodology}

\section{Specimen selection and preparation}

This study was approved by the University Ethics Committee (2.705.981). A total of 170 human mandibular first and second molars extracted for periodontal reasons not related to this study were inspected for specimen selection. Initially, specimens were maintained in $4 \%$ hypochlorite solution $(\mathrm{NaOCl})$ for 2 hours and cleaned by periodontal curettes. Periapical radiographs were taken from each tooth in a buccolingual and a mesiodistal direction. This stage aimed to select only similar radiographic morphology specimens with one isolated mesiobuccal canal and severely curved (20-35 $)$, according to Schneider's method (Schneider 1971, Aksoy et al. 2019).

Then, each tooth's crown was sectioned near the cementoenamel junction, and the mesiobuccal canal was individualized and standardized to a length of $13 \mathrm{~mm}$ from the anatomic apex, using a diamond disc. The observation of the following features, using the obtained periapical radiographs, a clinical microscope (10× magnification), and a size \#15 K-file (Dentsply Sirona Endodontics, York, PA, USA) excluded teeth from this study: dental caries, previous root canal treatment, root resorptions, root canal calcifications, initial apical diameter larger than a size \#15 K-file, dentinal cracks or root fractures (Aksoy et al. 2019). After the inspections, 50 teeth were selected for this study.

Firstly, a $5 \mathrm{~mL}$ of $2.5 \% \mathrm{NaOCl}$ solution was used, and root canals were explored with a size \#10 K-file (Dentsply Sirona Endodontics, York, PA, USA). The working length (WL) was established in the total root length (13 mm). The canal length was measured by inserting a size \#10 K-file (Dentsply Maillefer) into the canal until the file's tip became visible at the apical foramen. The intracanal contents were removed with a size \#15 K-file (Dentsply Sirona), and specimens were newly irrigated with $5 \mathrm{~mL}$ 
of $2.5 \% \mathrm{NaOCl}$. The smear layer was removed using $3 \mathrm{~mL}$ of 17\% EDTA for 3 minutes and a final irrigation with $5 \mathrm{~mL}$ of sterile saline solution was obtained. Root canals were dried using capillary tips (Ultradent Products, South Jordan, UT, USA) and sterile paper points in the WL. The apical foramen of each specimen was sealed with Z 100 composite resin (3M, Saint Paul, MN, EUA) to prevent apical bacterial leakage and create a closed-end canal producing the vapor lock effect (Alves et al. 2012). Afterward, the external apical surface was sealed with nail varnish.

In a laminar flow chamber, individual models of each specimen were prepared using silicone impression material (Zetaplus, Zhermack, RO, Italy) to simplify root handling and shaping. Teeth were prepared vertically up to the cervical third with the produced models, inserted into individual wells in 24-well cell culture plates (Costar, Washington DC, USA) and sterilized in an autoclave at $134^{\circ} \mathrm{C}$ for $15 \mathrm{~min}$. Then, aseptic conditions were confirmed after retaining teeth at $37^{\circ}$ during $24 \mathrm{~h}$, in which no bacterial growth was detected (Ferrer-Luque et al. 2014).

A suspension of E. faecalis (American Type Culture Collection 29212) was obtained by cultivation in brain heart infusion agar (BHI; Difco, Detroit, MD, USA) was prepared and standardized on the McFarland nephelometric scale $30 \mathrm{x} 10^{8}$ bacteria/mL. From the total sample, six specimens were selected as control, being filled solely with sterile BHI. Simultaneously, 44 roots were contaminated, being filled with the E. faecalis suspension using sterile micropipette tips. The specimens were incubated at $37{ }^{\circ} \mathrm{C}$ for 21 days, and the root canals contents were replaced with fresh BHI every 48 hours. This procedure was performed under laminar flow utilizing sterile micropipettes.

Two contaminated samples were subjected to scanning electron microscopy to confirm bacterial colonization and biofilm formation. Initially, they were fixed in $10 \%$ buffered formalin, longitudinally split, and dried in ascending ethanol concentrations. They were then dehydrated to their critical point in CO2 and sputter-coated with gold under vacuum. Specimens were examined by using a scanning electron microscope (JSM- 5800LV; JEOL, Tokyo, Japan).

Bacterial viability and intracanal sampling purity were checked every week by a selection of 2 random samples. For this, sterile size \#15 paper point was maintained into the root space during one min, then immediately spread in BHI and incubated at $37^{\circ} \mathrm{C}$ and $5 \% \mathrm{CO}_{2}$ for 24 hours. After growing, Gram staining and colony morphology on Columbia Agar with 5\% Sheep Blood (CA-SB) (Becton Dickinson GmbH, Heidelberg, BW, Germany) was performed.

\section{Initial quantification of bacterial contamination (S1)}

The root canal was rinsed with $1 \mathrm{~mL}$ of sterile saline solution to remove unattached cells. The initial sample (S1) was then obtained by the sequential use of 2 sterile \#15 paper points placed inside the root canal for 1 min each. Following this, paper points were transferred, with sterile tweezers'aid, to sterile polypropylene flasks (Prolab, São Paulo, SP, Brasil) containing 500 $\mu \mathrm{L}$ of sterile saline solution, vortexed for 30 seconds. From the resulting suspension, serial dilutions were prepared: $10^{-2}, 10^{-4}$, $10^{-5}$, and $10^{-6}$. Each sample dilution was plated in triplicate on BHI medium. The plates were incubated at $37^{\circ} \mathrm{C}$ for $48 \mathrm{~h}$, and the bacterial count was measured $(\mathrm{CFU} / \mathrm{ml})$.

\section{Root canal preparation}

Root canal preparation was performed by a single operator, an endodontist, who had been previously trained in each system. All files had single use. The protocol of each system followed the manufacturer's instructions. All systems were powered by a torque-controlled motor (X-Smart Plus; Dentsply Sirona Endodontics, York, PA, USA), set at the designated function according to the used system.

Forty-two specimens were randomly assigned to the following groups, according to the file system used ( $n=14$ ): ProTaper Next (G1), XP-Endo Shaper (G2) and Reciproc Blue (G3). WL was established in the total root length. 
G1 - ProTaper Next (Dentsply Sirona). Files were driven in continuous rotation. Instruments were applied at $300 \mathrm{rpm}$ and 2 $\mathrm{Ncm}$, in the "Protaper Next" function, in a crown-down technique using a gentle up-and-down motion. Firstly, the X1 file (17.04) was used for cervical and middle thirds shaping. Then, this file was reused until reaching the WL. Following this, the X2 file (25.06) was used in the same manner as previously described.

G2 - XP-Endo Shaper (FKG Dentaire). XP-Endo Shaper file (30.01 as initial taper; however, during use, this instrument expands to a minimum taper of 0.04) was activated in continuous rotation at $800 \mathrm{rpm}$ and $1.0 \mathrm{Ncm}$. Long and light up-and-down movements were applied inside root canals until reaching the cervical and middle thirds. After that, the file was reused in the same manner until reaching the WL.

G3 - Reciproc Blue (VDW GmbH). Reciproc Blue R 25 (25.08) was activated in a reciprocating motion, in the "Reciproc" function. The file was gently inserted with an up-and-down pecking motion with a maximum amplitude of $3 \mathrm{~mm}$ until the shaping of cervical and middle thirds was completed. After three up-and-down movements, when superior pressure was necessary to advance the instrument along the canal, the file was removed for cleaning the flutes. Then, the file was reused in the same manner until reaching the WL.

Root canals were irrigated during and after finishing instrumentation with a total volume of $10 \mathrm{~mL}$ sterile saline solution, delivered using a 24-G needle (Ultradent Products, South Jordan, UT, USA) using a peristaltic pump (LAP-101-3; MS Tecnopon, Piracicaba, SP, Brazil) using a flow rate of $5 \mathrm{~mL} / \mathrm{min}$. For this, the irrigation method was standardized. Initially, root canals were irrigated with $2.5 \mathrm{~mL}$ of saline. Then, after cervical and middle third shaping, $2.5 \mathrm{~mL}$ of saline was used for root canal irrigation while instruments were cleaned with sterile gauzes. Lastly, after completing the preparation of specimens in the WL, final irrigation with $5 \mathrm{~mL}$ of saline was performed. When a resistance requiring more apical pressure was detected during the use of all instruments, the file was removed, and the flutes were cleaned.

The six non-contaminated root canals were instrumented for each one of the three file systems $(n=2)$ and used as negative controls.

\section{Post root canal preparation - quantification of bacterial contamination (S2)}

After finishing root canal preparation, the quantification of bacterial contamination (S2) was obtained. For this, a size 25 sterile Hedstroem file (Dentsply Sirona) was introduced in the WL with circumferential strokes on all root canal surfaces (Machado et al. 2013). The file was then sectioned below the handle and, with the aid of sterile tweezers, dropped into a sterile Eppendorf containing $500 \mu \mathrm{L}$ of sterile saline solution. Following this, a sequential use of two sterile size \#25 paper points placed inside the root canal for one min each was performed. Collected paper points were stored in the same tube as the file and vortexed for $30 \mathrm{~s}$.

\section{Quantitative analysis by culture}

From the suspension, serial dilutions were prepared $\left(10^{-2}, 10^{-4}, 10^{-5}\right.$ and $\left.10^{-6}\right)$ and $0.1 \mathrm{~mL}$ aliquots of each were seeded on Petri plates containing BHI agar, which were incubated at $37^{\circ} \mathrm{C}$ and $5 \% \mathrm{CO}_{2}$ for $24 \mathrm{~h}$. After that, colonies were counted, and the number of colony-forming units per milliliter $(\mathrm{CFU} / \mathrm{mL})$ was calculated.

\section{Statistical analysis}

The log transformation of each CFU/mL count was performed, and statistical tests were applied using SPSS 23.0 (SPSS Inc., Chicago, IL, USA) as an analytical tool. The Wilcoxon test was used for intragroup analysis, and intergroup analysis was performed using the Kruskal-Wallis test. The level of significance for all analyses was set at $\mathrm{P}<.05$. 


\section{Results}

Scanning electron microscopy analysis of two specimens revealed that the root canal walls were densely colonized by E. faecalis cells forming biofilm-like structures (Figura 1).

Figure 1. Representative images in SEM of E. faecalis contamination by bacteria and biofilm-like structures on root canal walls. In (a, b), 5000X magnification (inputs) to the magnification 10000X.
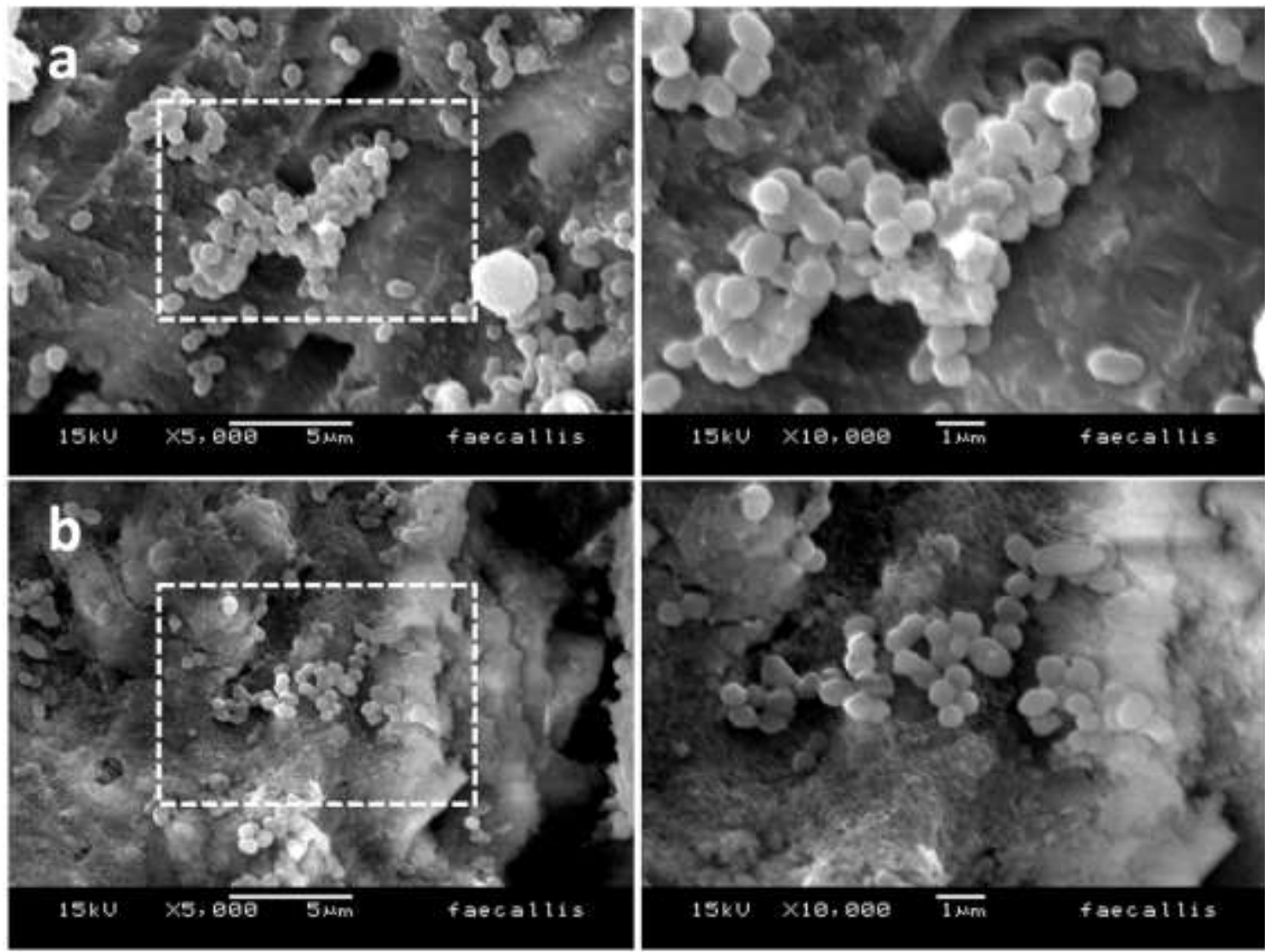

Source: Own authorship.

Successful colonization of the root canal was further confirmed by bacterial growth in all S1 samples (Table 1).

Table 1. Intracanal E. faecalis quantification [Mean (standard deviation - SD)] before (S1) and after root canal preparation (S2) and total bacterial percentage reduction for culture analysis, observed in all groups:

\begin{tabular}{lcccc}
\hline \multirow{2}{*}{ Groups } & \multicolumn{2}{c}{ Samples } & \multirow{2}{*}{$\mathbf{p}^{* *}$} & \multirow{2}{*}{ Total bacterial reduction } \\
\cline { 2 - 4 } & $1,21 \times 10^{6}\left(5,23 \times 10^{5}\right) \mathrm{a}$ & $2,53 \times 10^{4}\left(4,46 \times 10^{4}\right) \mathrm{b}$ & $\mathrm{p}=0.003$ & $1,19 \times 10^{6}\left(5,16 \times 10^{5}\right) \mathrm{A}$ \\
\hline $\boldsymbol{G 1}$ - ProTaper Next & $2,05 \times 10^{6}\left(1,02 \times 10^{6}\right) \mathrm{a}$ & $1,40 \times 10^{5}\left(1,37 \times 10^{5}\right) \mathrm{c}$ & $\mathrm{p}=0.001$ & $1,91 \times 10^{6}\left(1,03 \times 10^{6}\right) \mathrm{B}$ \\
\hline $\boldsymbol{G 2}-$ XP-Endo Shaper & $2,60 \times 106(1,38 \times 106) \mathrm{a}$ & $1,52 \times 105(1,40 \times 105) \mathrm{c}$ & $\mathrm{p}=0.009$ & $2,45 \times 10^{6}\left(1,31 \times 10^{6}\right) \mathrm{B}$ \\
\hline $\boldsymbol{G 3}$ - Reciproc Blue & - & - & - & $\mathrm{p}=0.012$ \\
\hline $\mathbf{p}^{*}$ & & & &
\end{tabular}

$\mathrm{p}^{*}$ : comparison between groups. Different uppercase letters indicate statistically different values $(\mathrm{p}<0.05)$ between groups. $\mathrm{p}^{* *}$ : comparison between S1 and S2 within each group. Different lowercase letters indicate statistically different values $(\mathrm{p}<0.05)$ between S1 and S2 samples. Source: Authors. 
Table 1 reveals the results of E. faecalis counts before (S1) and after root canal preparation (S2) and the total bacterial percentage reduction for culture analysis, observed in all groups. All endodontic systems presented effective bacterial reduction. However, despite that bacterial levels were reduced after preparation with ProTaper Next ( $\mathrm{p}=0.003)$, XP-Endo Shaper ( $\mathrm{p}=0.001)$ and Reciproc Blue ( $\mathrm{p}=0.009$ ), all groups still had bacterial growth. It was revealed significant differences between values of total bacterial elimination obtained by groups ( $\mathrm{P}=0.012)$. ProTaper Next displayed the highest $E$. faecalis reduction $(\mathrm{P}<0.05)$, while XP-Endo Shaper and Reciproc Blue systems presented similar results $(\mathrm{P}>0.05)$.

\section{Discussion}

This study aimed to evaluate the performance of recently introduced single file systems compared to a conventional NiTi technique in the reduction of intracanal E. faecalis in severely curved canals. Severely curved mesiobuccal canals from mandibular molars were selected due to the considerable challenge they represent for proper cleaning and disinfection, reflecting the bacterial reduction in specimens with this complex anatomy (Moshari et al. 2015, Lacerda et al. 2017). Also, mandibular molars were selected based on their high prevalence for endodontic treatments and their significant association with periapical disease (Kirkevang et al. 2007; Siqueira \& Rôças. 2004).

The present results showed that instrumentation with the different systems promoted a highly significant reduction in the intracanal bacterial counts independent of the system used $(\mathrm{p}<0,05)$, however, despite the bacterial reduction after the instrumentation, all groups still tested positive for E. faecallis, which is following previous studies (Krokidis et al., 2017; Carvalho et al., 2019; Üreyen et al., 2019) and highlights the need for the deployment of new files capable of increasing the disinfection of root canal complexities and irregularities.

The isolated strain of E. faecallis was selected based on its survival characteristics associated with its prevalence in cases of endodontic failure and because it is widely used in previous studies with similar methodology (Neto et al. 2012, FerrerLuque et aal.2014). E. faecalis resistance seems to be a reference for preparation system effectiveness since its reduction in root canals would prove the elimination of other less-resistant microorganisms (Neto et al. 2012).

Culture analysis is commonly used to evaluate bacterial reduction according to different preparation techniques and was utilized in the present study to act as a comparison parameter with previous investigations (Machado et al. 2013, Siqueira et al. 2013, Machado et al. 2017, Üreyen et al. 2019). However, E. faecalis is can enter into a stationary phase when under stress, being viable but undetectable in conventional CFU counts if in this condition (Rôças et al. 2013). Besides, the dilution step required for counting units 'analysis may bias the method since it may render bacterial quantification imprecise (Rôças et al. 2013). Nevertheless, a previous study that used a similar in vitro protocol showed no significant difference for bacterial counts between culture and qPCR in post-treatment samples (Alves et al., 2012).

The present experimental design has some noteworthy aspects. Efforts by radiological analysis and anatomy classification were undertaken to ensure reliable comparability between groups. This reduced anatomical biases and allowed to increase this study's internal validity (Alves et al. 2012, Siqueira et al. 2013, Aksoy et al. 2019). In addition to anatomy, it is also relevant to consider other experimental conditions of the study. The total root length, WL preparation, preparation technique, and irrigation parameters were standardized in all groups (Neto et al. 2012; Machado et al. 2013, Üreyen et al. 2019). Furthermore, post preparation sample was performed using scraping a Hedstroem file in dentinal walls previously to the use of paper points. This step permitted to include biofilm remnants harbored in non-instrumented areas or dentinal debris, which could influence file systems 'performance in the bacterial reduction (Machado et al. 2013).

ProTaper Next system was significantly more effective in bacterial reduction than XP-Endo Shaper and Reciproc Blue groups $(\mathrm{p}<0,05)$. However, ProTaper Next has previously demonstrated positive results in comparison with other systems, such 
as the self-adjusting file (SAF; ReDent-Nova, Ra'anana, Israel), which is a single file system, Hyflex CM nickel-titanium rotary instruments (Coltene/ Whaladent Inc; Cuyahoga Falls, OH, USA), and K3XF nickel-titanium rotary instruments (SybronEndo, Orange, CA, USA) (Karatas et al., 2015; Tewari et al., 2016). ProTaper Next files have a parallelogram-shaped cross-section that shapes the root canals asymmetrically by two contact points on dentinal walls during a continuous rotation movement. As a result, these instruments present a larger area of escape reducing lateral compaction, which results from the coronal removal of dentinal debris (Machado et al., 2017). This may also explain the superior E. faecalis reduction presented by ProTaper Next system.

The XP-Endo Shaper and the Reciproc Blue systems showed similar efficacy in bacterial reduction ( $\mathrm{P}>0.05)$. Regarding the XP-Endo Shaper system, the MaxWire alloy is used so that files can achieve greater flexibility and resistance to cyclic fatigue. In addition to that, this file has a reinforcing tip (Booster Tip) that allows started shaping the root canals with an initial diameter smaller than the original diameter (Aksoy et al. 2019). According to the manufacturer's instructions, at $37^{\circ} \mathrm{C}$, the instrument can expand from an initial taper of $30 / 0.01$ to a final canal preparation of a minimum of $30 / 0.04$, adapting to the morphology irregularities of the root canal system. In turn, Reciproc Blue system presents an S-shaped cross-section that allows deeper cutting and favors the removal of smear layer and debris (Keles et al. 2019). Its NiTi wire processing method uses a visible layer of titanium oxide that results in a distinct blue color, which changes its molecular structure to generate greater flexibility and resistance to cyclic fatigue (De-Deus et al. 2019).

Lastly, the limitations of this study must be pointed out. Whereas only mesiobuccal canals were used and the presence, size, and volume of the isthmus were not considered, this anatomy can influence the results once the isthmus represents an entire system with connections between roots canal (Tahmasbi et al., 2017), which may reflect in the remaining contamination of each group. Also, to isolate the action of files from the chemical action of irrigating solutions, only sterile saline was used during irrigation (Machado et al., 2013; Üreyen et al., 2019;). This allowed observing the isolated mechanical action of endodontic files but did not reflect endodontic treatment's clinical conditions. Further clinical studies using different irrigating solutions should be performed to evaluate the Reciproc Blue and XP-Endo Shaper systems 'effectiveness in severely curved canals.

\section{Conclusion}

In conclusion, within this study's limitations, ProTaper Next showed the most significant antibacterial action when compared to the XP-Endo Shaper and Reciproc Blue systems. No instrumentation system rendered root canals completely free from bacteria.

\section{References}

Aksoy, Ç., Keriş, E. Y., Yaman, S. D., Ocak, M., Geneci, F., \& Çelik, H. H. (2019). Evaluation of XP-endo Shaper, Reciproc Blue, and ProTaper Universal NiTi Systems on dentinal microcrack formation using micro-computed tomography. Journal of endodontics, 45(3), $338-342$.

Alves, F. R. F., Rôças, I. N., Almeida, B. M., Neves, M. A. S., Zoffoli, J., \& Siqueira Jr, J. F. (2012). Quantitative molecular and culture analyses of bacterial elimination in oval - shaped root canals by a single - file instrumentation technique. International endodontic journal, 45(9), 871-877.

Ankrum, M. T., Hartwell, G. R., \& Truitt, J. E. (2004). K3 Endo, ProTaper, and ProFile systems: breakage and distortion in severely curved roots of molars. Journal of endodontics, 30(4), 234-237.

Bürklein, S., Mathey, D., \& Schäfer, E. (2015). Shaping ability of P ro T aper NEXT and BT - R a C e nickel-titanium instruments in severely curved root canals. International endodontic journal, 48(8), 774-781.

Carvalho, M. C., Zuolo, M. L., Arruda-Vasconcelos, R., Marinho, A. C. S., Louzada, L. M., Francisco, P. A., \& Gomes, B. P. F. D. A. (2019). Effectiveness of $\mathrm{XP}-$ Endo Finisher in the reduction of bacterial load in oval-shaped root canals. Brazilian oral research, 33.

De-Deus, G., Barino, B., Zamolyi, R. Q., Souza, E., Júnior, A. F., Fidel, S., \& Fidel, R. A. S. (2010). Suboptimal debridement quality produced by the singlefile F2 ProTaper technique in oval-shaped canals. Journal of Endodontics, 36(11), 1897-1900. 
De - Deus, G., Belladonna, F. G., Zuolo, A. S., Simões - Carvalho, M., Santos, C. B., Oliveira, D. S., \& Silva, E. J. N. L. (2019). Effectiveness of Reciproc Blue in removing canal filling material and regaining apical patency. International endodontic journal, 52(2), 250-257.

Ferrer - Luque, C. M., Bejarano, I., Ruiz - Linares, M., \& Baca, P. (2014). Reduction in E nteroccocus faecalis counts-a comparison between rotary and reciprocating systems. International endodontic journal, 47(4), 380-386.

FKG XP Endo Shaper. (2017) https://www.fkg.ch/sites/default/files/201704_fkg_xp_endo_shaper_brochure_v4_en_web.pdf.

Karataş, E., Gültekin, E., Arslan, H., Alsancak, M., \& Topçu, M. Ç. (2015). Evaluation of instrumentation systems in reducing E. faecalis from root canals: TF adaptive and ProTaper next versus single file systems. The International journal of artificial organs, 38(3), 161-164.

Keles, A., Ozyurek, E. U., Uyanik, M. O., \& Nagas, E. (2019). Effect of temperature of sodium hypochlorite on cyclic fatigue resistance of heat-treated reciprocating files. Journal of endodontics, 45(2), 205-208.

Kirkevang, L. L., Vaeth, M., Hörsted - Bindslev, P., Bahrami, G., \& Wenzel, A. (2007). Risk factors for developing apical periodontitis in a general population. International Endodontic Journal, 40(4), 290-299.

Krokidis, A., Bonfanti, C., Cerutti, A., Barabanti, N., Zinelis, S., \& Panopoulos, P. (2017). Comparative analysis of SAF, Protaper Next and BT - Race in eliminating Enterococcus faecalis from long oval canals: An ex vivo study. Australian Endodontic Journal, 43(3), 110-114.

Lacerda, M. F., Marceliano-Alves, M. F., Pérez, A. R., Provenzano, J. C., Neves, M. A., Pires, F. R., ... \& Siqueira Jr, J. F. (2017). Cleaning and shaping oval canals with 3 instrumentation systems: a correlative micro-computed tomographic and histologic study. Journal of Endodontics, 43(11), 1878-1884.

Machado, M. E. L., Nabeshima, C. K., Leonardo, M. F. P., Reis, F. A. S., Britto, M. L. B., \& Cai, S. (2013). Influence of reciprocating single - file and rotary instrumentation on bacterial reduction on infected root canals. International endodontic journal, 46(11), 1083-1087.

Machado, M. E. D. L., Nabeshima, C. K., Caballero-Flores, H., Elmadjian-Filho, M., Duarte, M. A. H., Odinola-Zapata, R., \& Cai, S. (2017). Instrument design may influence bacterial reduction during root canal preparation. Brazilian dental journal, 28(5), 587-591.

Moshari, A. A., Akhlaghi, N. M., Rahimifard, N., \& Darmiani, S. (2015). Reduction of Enterococcus faecalis in curved root canals after various sizes and tapers of canal preparation. Journal of conservative dentistry: JCD, 18(4), 306.

Mounce, R. (2007). Negotiating challenging mid root curvatures: rounding the bend. Dentistry today, 26(2), 108-110.

Neto Matos, M., Santos, S. S. F., Leão, M. V. P., Habitante, S. M., Rodrigues, J. R. D. D., \& Jorge, A. O. C. (2012). Effectiveness of three instrumentation systems to remove Enterococcus faecalis from root canals. International endodontic journal, 45(5), 435-438.

Patnana, A. K., \& Chugh, A. (2018). Endodontic management of curved canals with protaper next: A case series. Contemporary clinical dentistry, 9(Suppl 1), S168.

Plotino, G., Cortese, T., Grande, N. M., Leonardi, D. P., Di Giorgio, G., Testarelli, L., \& Gambarini, G. (2016). New technologies to improve root canal disinfection. Brazilian dental journal, 27(1), 3-8.

Rôças, I. N., Lima, K. C., \& Siqueira Jr, J. F. (2013). Reduction in bacterial counts in infected root canals after rotary or hand nickel-titanium instrumentationa clinical study. International endodontic journal, 46(7), 681-687.

Schilder, H. (1974). Cleaning and shaping the root canal. Dent Clin North Am, 18, 269-296.

Schneider, S. W. (1971). A comparison of canal preparations in straight and curved root canals. Oral surgery, Oral medicine, Oral pathology, 32(2), 271-275.

Siqueira Jr, J. F., \& Rôças, I. N. (2004). Polymerase chain reaction-based analysis of microorganisms associated with failed endodontic treatment. Oral Surgery, Oral Medicine, Oral Pathology, Oral Radiology, and Endodontology, 97(1), 85-94.

Siqueira Jr, J. F., Alves, F. R., Versiani, M. A., Rôças, I. N., Almeida, B. M., Neves, M. A., \& Sousa-Neto, M. D. (2013). Correlative bacteriologic and microcomputed tomographic analysis of mandibular molar mesial canals prepared by Self-Adjusting File, Reciproc, and Twisted File systems. Journal of endodontics, 39(8), 1044-1050.

Tahmasbi, M., Jalali, P., Nair, M. K., Barghan, S., \& Nair, U. P. (2017). Prevalence of middle mesial canals and isthmi in the mesial root of mandibular molars: an in vivo cone-beam computed tomographic study. Journal of endodontics, 43(7), 1080-1083.

Tewari, R. K., Ali, S., Mishra, S. K., Kumar, A., Andrabi, S. M. U. N., Zoya, A., \& Alam, S. (2016). Mechanical reduction of the intracanal enterococcus faecalis population by Hyflex CM, K3 XF, ProTaper Next, and two manual instrument systems: an in vitro comparative study. Journal of investigative and clinical dentistry, 7(2), 168-173.

Üreyen Kaya, B., Erik, C. E., Sesli Çetin, E., Köle, M., \& Maden, M. (2019). Mechanical reduction in intracanal Enterococcus faecalis when using three different single - file systems: an ex vivo comparative study. International endodontic journal, 52(1), 77-85.

Versiani, M. A., Pécora, J. D., \& de Sousa-Neto, M. D. (2011). Flat-oval root canal preparation with self-adjusting file instrument: a micro-computed tomography study. Journal of endodontics, 37(7), 1002-1007. 